\title{
Influential Factors of Exchange Rate Behaviour in Ghana: A Cointegration Analysis
}

\author{
Samuel Antwi ${ }^{1,2}$, Eric Kofi Boadi ${ }^{2} \&$ Eugene Oware Koranteng ${ }^{2}$ \\ ${ }^{1}$ School of Finance and Economics, Jiangsu University, Jiangsu, China \\ ${ }^{2}$ Accountancy Department, Koforidua Polytechnic, Koforidua, Ghana \\ Correspondence: Samuel Antwi, School of Finance and Economics, Jiangsu University, 301 Xuefu Road, \\ Zhenjiang, Jiangsu, China. E-mail: samyantwi@yahoo.com
}

Received: November 29, 2013

Accepted: December 10, 2013

Online Published: January 23, 2014

doi:10.5539/ijef.v6n2p161

URL: http://dx.doi.org/10.5539/ijef.v6n2p161

\begin{abstract}
This study investigates whether short run movements in the exchange rates could be predicted by the past history of GDP, consumer price index, imports, exchange rates themselves and government expenditure. Secondly, the study investigates if there are stable long run equilibrium relationships among the variables. Using quarterly data spanning twenty four years, the techniques of cointegration, vector error correction mechanism, granger causality test, variance decomposition and impulse response functions have been used to analyze the data. The study reveals that there are significant long run equilibrium relationships among the variables. It also reveals that government expenditure is significant in forecasting the exchange rate movements. In addition, the past history of the exchange rates has dominant effects in forecasting the exchange rates. It is recommended that government expenditure should be controlled to reduce drastic fluctuations in the exchange rate in the short run.
\end{abstract}

Keywords: exchange rate behavour, cointegration, influential factors, Ghana

\section{Introduction}

The exchange rate is one of the macroeconomic variables that occupy a central place in the management of most economies. The volume of empirical studies on the subject attests to this assertion (Abuaf \& Jorion, 1990; Calderon \& Duncan, 2003; Cheung \& Lai, 2001; Diebold, Husted, \& Rush, 1991; MacDonald, 1993; Sarno \& Taylor, 1998; Taylor, 1995). The issue becomes more imperative especially for countries that depend heavily on importation of essential commodities such as crude oil and raw materials for industrial production. Given the foreign prices of these products, rises in the exchange rate result in higher prices for domestic consumers. Because of the inflationary effect of devaluation, policymakers in the sixties and seventies generally maintained a fixed exchange rate with occasional devaluations. There was extreme reluctance on the part of most governments during this period to vary the exchange rate because of concern over adverse political consequences (Harrigan \& Oduro, 2000). Because of an unfavorable balance of payments and the deflationary effect of the fixed exchange on the Ghanaian economy, the Cedi was devalued in 1971 during a Busia government (Dordunoo, 1994). Not more than six weeks after the devaluation, the Busia government was overthrown in a military coup and the currency revalued by $29 \%$ (Osei, 1996).

The economy of Ghana persistently declined since the early 1960s (Jebuni, Sowa, \& Tutu, 1991). GDP declined at the rate of 1.3 percent between 1960 and 1982. By 1983, the rate of inflation had climbed to 123 percent. Food production also declined over the years while the population was growing at a staggering 3.2 percent. All these factors meant economic hardship for the country. Balance of payment difficulties and a shortage of foreign exchange also meant low industrial output since importation of essential raw materials could not be imported. Most industries in Ghana were operating greatly below capacity prior to 1983. The severe economic downturn in the late 1970s and early 1980s compelled the Provisional National Defense Council (PNDC) government in 1983 to implement the International Monetary Fund (IMF) /World Bank supported Economic Recovery Program (ERP). The ERP sought to remove controls and distortions in the economy so as to restore incentives for economic growth and development (Ocran, 2007). A lot of reforms were introduced during the process including the deregulation (liberalization) of the exchange rate determination (Kwakye \& Sowa, 1993). Because of the political consequences of devaluation, a gradual systematic approach was adopted toward this goal. By the early 1990s, the exchange rate was fully liberalized with the legalization of foreign exchange bureaux to operate as legal entities (Bhasin, 2004). The fact that macroeconomic variables were important in determining exchange rates was again made evident in 2008 when the 
Cedi depreciated by 24.7 percent against the US Dollar. This was associated with a substantial growth in government expenditure of about 42 percent. The main objective of this study is to determine the variables that explain variation in the exchange rate.

\section{Methodology}

\subsection{Theoretical Framework}

The model assumes that Ghana is a small country in the world capital market and hence faces a given foreign interest rate. Ghana, being a market economy, allows movement of capital into and out of the country with slight restrictions. This capital mobility will ensure the equalization of net expected yields so that the domestic interest rate, adjusted for the rate of depreciation, will equal the interest rate of her trading partners. This is summarized in equation (1). Recalling (1) and expressing the sport exchange rate in terms of other variables, we have

$$
\operatorname{In} E_{t}=\operatorname{In} E_{t+1}-r+r^{*}
$$

where $E_{t}, E_{t+1}, r$ and $r^{*}$ denote the current spot exchange rate, the long run exchange rate, the domestic interest rate and foreign interest rate in that order. From equation (1), it can be seen that the spot exchange rate is influenced by the domestic interest rate. The logical progression then is to find out how the domestic interest rate is determined. In this framework, the domestic interest rate is determined by the conditions in the money market. The money market equilibrium condition requires that the real money supply equates real money demand. For now, we assume money supply is exogenously determined but will be relaxed later. The real demand for money is assumed to depend on the rate of interest and income. The equilibrium in the money market is represented in the equation. Solving for Gives u equation (2) and substituting it into (1), we have

$$
\operatorname{In} E_{t}=\operatorname{In} E_{t+1}-\{1 / \lambda(\phi \operatorname{In} Y-\operatorname{In} M+\operatorname{In} P)\}+r^{*}
$$

As suggested by Becker (2006), economic models are abstractions of the real world for the purposes of studying the relationship among some variables of interest. For this reason, economic models should not be proliferated with variables. Guided by this suggestion, money supply will be assumed to depend on domestic credit, which is made available to the public by commercial banks, budget deficit which is proxied by government expenditure and balance of payments disequilibrium proxied by imports. That is

$$
\text { InM }=f_{1}(G O V E X P, D O M C R, I M P O R T S)
$$

Substituting equation (3) into (2) we have

$$
\operatorname{In} E_{t}=\operatorname{In} E_{t+1}-\left\{1 / \theta \lambda f_{1}(G O V E X P, D O M C R, I M P O R T S)\right\}+r^{*}
$$

Functionally, equation (4) can be written more compactly as $e=f_{2}\left(y, b u d\right.$, domcr, bop, $\left.p, r^{*}\right)$ where the current spot exchange rate depends on national income, government expenditure, domestic credit, imports, domestic price level and foreign interest rate. Since Ghana is a small country in respect of international transactions, foreign interest rate may influence the workings of the Ghanaian economy but the effect is not expected to be significant. For this reason, foreign interest rates will be dropped from the model. For the purpose of estimation, balance of payments is proxied by the imports, domestic price level of the consumer price index, national income by the nominal GDP and the domestic credit by the amount of credit made available to the banking public by the various commercial banks. We expect the nominal exchange rate to have a positive relationship with all the variables in the model except national income that can be either positive or negative.

\subsection{Definition of Variables}

Exchange rate refers to the quantity of domestic currency that is needed to purchase a unit of foreign currency. The nominal gross domestic product (GDP) refers to the total money value of all goods and services currently produced in a country over a given period usually one year. Domestic credit refers to the total amount of credit facilities made available to the general banking public by the various financial institutions. The consumer price index is the weighted average of price of a basket of goods and services used by an average consumer. The level of variation in this index measures the rate of inflation.

\subsection{Estimation Technique}

Ordinary Least Squares (OLS) are one of the techniques used widely in econometric model estimation. For results from OLS estimation to be valid, the various assumptions underlying the model must be satisfied. Of particular interest are the assumptions that the data to be used for the estimation must be stationary and that the disturbance term must not correlate with the regressors. A VAR model expresses the current value of an endogenous variable as a function of deterministic terms and the lagged values of the endogenous variables. In other words, in VAR, 
each endogenous variable is explained by its lagged or past value and the lagged values of all other endogenous variables in the model. This definition of VAR can, however, be modified such that other deterministic variables such as constants in each equation, the time trend t, dummy, and exogenous variable can be included in the model. The variables in the VAR can be expressed using a vector. In this study,

$$
Y_{t}=(y, \text { gov, exp,domcr, imports, } p, \text { exch })^{1}
$$

is a vector of endogenous variables consisting of the nominal GDP, government expenditure, domestic credit, import, consumer price index and nominal exchange rate respectively. The basic p-order vector autoregressive (VAR [p]) model has the general form

$$
Y_{t}=u+\Pi_{1} Y_{t-1}+\Pi_{2} Y_{t-2}+\ldots \ldots .+\Pi_{p} Y_{t-p}+\varepsilon_{t}
$$

for $t=1,2, \ldots T$ where $\prod_{\mathrm{i}}$ are $k x k$ coefficient matrices, $\varepsilon_{t}$ is a $k x 1$ unobservable zero mean white noise vector process and $u$ is a $\mathrm{kx} 1$ vector of constants. Before estimating equation (6), it is important to determine the order of the VAR model. The lag length for the $\operatorname{VAR}(p)$ model may be determined using model selection criteria. The general approach is to fit $\operatorname{VAR}(p)$ models with orders $p=1,2, \ldots P_{\max }$ and choose the value $\mathrm{p}$ which minimizes some model selection criteria (Greene, 2002). Model selection criteria for VAR (p) models have the form

$$
I C(p)=\operatorname{In} \tilde{\Sigma}(p)+C_{T}, \psi(n, p)
$$

Where $\tilde{\Sigma}(p)=T^{-} \sum_{t=1}^{T} \hat{\varepsilon}_{t} \hat{\varepsilon}_{t}^{I}$ is the residual covariance matrix without a degree of freedom correction from VAR $(p)$ model, $C_{T}$ is a sequence indexed by the sample $\operatorname{size} T$, and $\psi(n, p)$ is a penalty function which penalizes large VAR $(p)$ models. The three most common information criteria are the Akaike (AIC), Schwarz-Bayesian (BIC) and Hannan-Quinn (HQ). In this study, Hannan-Quinn (HQ) criterion has been used to determine the order of VAR. There are, however, other methods for selecting the appropriate lag length. After the correct lag length is chosen, the model is then estimated using OLS. Although the equation system in VAR can be exceedingly large, it is, in fact, a seemingly unrelated regression model with identical regressors. As such, the equations should be estimated separately by OLS (Greene, 2002). To guard against the dangers of spurious regressions and erroneous inferences emanating from the use of nonstationary data, tests of nonstationarity are conducted. The common type of nonstationarity in economic time series is the presence of unit root. The unit root tests are used to determine the order of integration of the variables. There are several ways of conducting the unit root tests. This study uses Augmented Dickey-Fuller (ADF) test and Phillips-Perron (PP) test. The ADF statistic tests the null hypothesis that the variables under consideration contain a unit root. The ADF test, for instance, is based on autoregression of each variable with lagged difference terms ranging from one to six added to ensure that the error terms do not correlate. The model with the least value of Akaike Information Criterion (AIC) is then chosen. If the variables are integrated of order zero, I(0), inferences from the OLS estimation will be valid (Greene, 2002). If the variables are integrated of order one, I(1), then, there is a possibility of invalid inferences from the OLS estimation. Johansen formulates a process of determining the number of cointegrating relationships in a VAR model. The context of analysis is an unrestricted path order VAR in K variables, formulated as a Vector Error Correction (VEC) model (Patterson, 2000). Equation (7) can be reformulated in terms of first differences and levels. This follows from Granger Representation Theorem, which states that if the $\mathrm{K} \times 1$ vector of variables $Y_{t}$ is cointegrated, then the equation (8) can be expressed as a VEC model. The VEC form of (10) is

$$
\Delta Y_{t}=u+\Gamma_{1} Y_{t-1}+\ldots \ldots . .+\Gamma_{p-1} Y_{t-(p-2)}-\ldots \ldots .+\Pi Y_{t-1}+V_{t}
$$

where the $\Gamma_{1}$ are functions of the $\Pi_{i}$ which capture the short-run dynamics involving the differenced variables and $\Pi=\mathrm{I}-\Pi_{\mathrm{i}}-\ldots-\Pi_{\mathrm{n}}$ is a matrix capturing the number of long run equilibrium relationships among the $Y_{t}$ variables. The vector $\Delta Y_{t}$ contains the first differenced variables and $Y_{t}$ is a vector of the variables in their levels. If the vector $Y_{t}$ is integrated of order one I(1), casual inspection of (8) seems to suggest there is an imbalance in model (4.8) since the left-hand side (LHS) is stationary while the right-hand side (RHS) appears to be nonstationary because it contains $Y_{t-1}$, which is nonstationary. In order to balance the time series property on the LHS of (8), the RHS must also be $\mathrm{I}(0)$. What can solve this contradiction lies in whether there is a linear combination of $\mathrm{I}(1)$ variables in $Y_{t-1}$ which is $\mathrm{I}(0)$. If so, equation (8) is balanced in its time series properties and when this occurs, the variables in the vector $\ldots$ are side to be cointegrated. Let $r$ denote the number of cointegrating vectors in equation (8). The matrix $\Pi$ can be decomposed into two matrices, $\Pi=\alpha \beta^{2}$ where $\alpha$ is a $k \times r$. matrix of adjustment coefficients with each column associated with one of the cointegrating vectors and $\beta^{2}$ is $r x k$ matrix of cointegrating vectors among the $k$ variables. The dimension of $\Pi$ is, therefore, $k x k$ the rank of, $\Pi, p(\Pi)$ is equal to the number of cointegrating vectors (8) denoted by $r$. The number of cointegrating vectors can be checked by calculating the eigenvalues, $\lambda_{i}$, of $\Pi$. The behavior of $Y_{t}$ vector depends on the values of $\lambda$ that solve the characteristic equation 


$$
\left|\lambda^{p} I-\lambda^{p-1} \Pi_{1} \ldots-\lambda \Pi_{p-1}-\Pi_{p}\right|=0
$$

The $\lambda_{i}$ are ordered such that $\lambda_{1}>\lambda_{2}>\lambda_{3} \ldots \lambda_{k}$ Johansen has developed two tests that facilitate the determination of the number of cointegrating vectors $r$ in the model. The trace statistic is given as:

$$
\left(r_{0} / k\right)=-T \sum_{1=r_{0}+1}^{k} \operatorname{In}\left(1-\hat{\lambda}_{i}\right)
$$

The implications of the test are that If $p(\Pi)=k$ meaning each root in $\Pi$ has modulus less than one, $\Pi$ will have full rank and be nonsingular. All the variables in equation (9) will be I(0), and unrestricted OLS estimates will yield identical inferences about the parameters. If $p(\Pi)=\mathrm{r}<k$. This situation will occur if there is a unit root with multiplicity $(k-r)$ and the remaining roots are numerically less than one. The $Y_{t}$ vector will be $\mathrm{I}(1)$ or higher and $\Pi$ may be expressed as the outer product of two (kxr) matrices, each of rank $r$. The RHS of equation (9) then contains $\mathrm{r}$ cointegrating vectors. In other words, equation (8) must be expressed as equation ( 9 incorporating both short-run dynamics and static equilibrium. This model must reflect the number of cointegrating vectors. If $p(\Pi)=0$. This will occur only when $\Pi=0$, implying no long run relationships among the variables and the model must be expressed solely in terms of first differences of the variables (Johnston \& DiNardo, 1997). The results of Johansen tests will determine how the model will be formulated finally. This is because the final estimation must reflect the number of cointegrating vectors in the model. The presence of cointegration in a given model does not mean that all the variables tend to move together. It only suggests that some of the variables tend to drift together. Likelihood Ratio (LR) test can be used to determine which variables to include in a long run relationship. The LR test simple compares the maximum likelihood of observing an endogenous variable in the presence of its entire explanatory variables (unrestricted model) to the maximum likelihood of observing the same endogenous variable in the presence of some of its explanatory variables (restricted model). This statistic has a chi-squared $\left|x^{2}(q)\right|$ distribution with q degrees of freedom being the number of explanatory variables excluded from the restricted model. If the excluded variable(s) are significant, the likelihood ratio will be large leading to the rejection of the null hypothesis. This method is used to exclude insignificant variable from a given long run relationship. One shortcoming of this technique is that it is asymptotically valid and may be biased in small samples. Granger causality test determines whether the lagged values of a particular variable are significant in predicting the regressor and can be based on simple F tests in the single equations of the VAR model (Greene, 2002)

Mathematically, variable $x_{t}$ is said not to granger cause variable $Y_{t}$ if

$E\left(y_{t} \mid y_{t-1,} x_{t-1}, x_{t-2, \cdots}\right)=E\left(y_{t} \mid y_{t-1}\right)$, where $E$ is the conditional expectation (Greene, 2002). Specifically, we test whether the past values of the nominal GDP, CPI, government expenditure, imports and domestic credit contain useful information for predicting exchange rates-Cedi-Dollar and Cedi-Pound. This test is performed on the lagged values of a particular variable one at a time. The endogenous variables can be expressed as a moving-average process under some conditions. Recalling equation (9) and using the lag operator notation, the general VAR can be expressed as

$$
Y_{t}=u+\Pi_{1} L Y_{t}+\Pi_{2} L^{2} Y_{t}+\ldots \Pi_{p} L^{p} Y_{t}+\varepsilon_{t}
$$

From (10),

$$
\Pi Y_{t}=u+\varepsilon_{t}
$$

where $\left(l_{p}-\Pi_{1} L-\Pi_{2} L^{2}-\ldots-\Pi_{p} L^{p}\right)=\mid \Pi$. For $Y_{t}$ to be expressed in terms of $\varepsilon_{t}$ and $u$, the matrix $\Pi$ must have full rank. The presence of unit root implies that the matrix $\Pi$ has reduced rank and therefore not invertible. This shows that VAR containing nonstationary variables cannot have a moving average representation. Instead, we must decompose the characteristic polynomial into a unit-root part and a stationary invertible part, written as the product:

$$
(1-L) Y_{t}=\Delta Y_{t} \Pi^{*-1} u+\Pi^{*-1} \varepsilon_{t}
$$

Equation (12) tells us that VAR involving stationary variables have a moving average representation since the matrix $\Pi^{*}$ is now invertible. Thus, if the variables are nonstationary, the VAR can be estimated using the first differences (Henry \& Juselius, 2000). The moving average model is then estimated and the parameter estimates plotted to give us the impulse response functions. Plotting the impulse response functions (i.e., plotting the coefficients of the innovations against the time horizon) is a practical way to visually represent the behavior of the series in response to the various shocks. To illustrate, consider a two-variable first order VAR system

$$
y_{1 t}=a_{11} y_{1 t-1}+a_{12} y_{2 t-1}+\varepsilon_{1 t}
$$




$$
y_{2 t}=a_{21} y_{1 t-1}+a_{22} y_{2 t-1}+\varepsilon_{2 t}
$$

A shock in $\varepsilon_{1 t}$ has an immediate and one-for-one effect on $y_{1 t}$, but no effect on $y_{2 t}$. In period $t+1$, that shock in $y_{1 t}$ affects $y_{1 t+1}$ through the first equation and also affect $y_{2 t+1}$ through the second equation. These effects work through $t+2$, and so on. Thus, a shock in one innovation in the VAR sets up a chain reaction over time in all variables in the VAR system. Impulse response functions calculate these chain reactions (Johnston \& DiNardo, 1997). Variance decomposition or forecast error variance decomposition indicates the amount of information each variable contributes to the other variables in a VAR model. While impulse response functions trace the effects of shock to one endogenous variable on the other variables in the VAR, variance decomposition separates the variation in an endogenous variable into the component shocks to the VAR. In other words, variance decomposition assesses the importance of different shocks by determining the relative share of variance that each structural shock contributes to the total variation of each variable. PcGive and Eviews econometric softwares, which have routines capable of VAR analysis, have been used in the study. PcGive was used to do the following: natural log transformation of the data; time series plot of the variables; unit root tests; lag length selection tests and; forecasting the exchange rates. Eviews, on the other hand, was used in performing the following tasks: Johansen cointegratioin tests; error correction model estimation; computing error variance decompositions and; estimation of impulse response functions.

\subsection{Data Sources}

Quarterly data for this study were obtained from three sources namely, the Ghana Statistical Service (GSS, 2012), the Bank of Ghana (BOG, 2012) and International Financial Statistics (IFS) of the IMF, the paper version (2012) covering the period 1989-2012. The nominal GDP and consumer price index were obtained from the GSS. Domestic credit, measured in millions of Ghana Cedis, is obtained from the various editions of IFS. The quarterly exchange rates are indicative of the interbank market rates (1989-2012) obtained from BOG. Annual government expenditure, measured in thousands of Ghana Cedis, and imports, measured in millions of US Dollars, were all obtained from BOG.

\section{Results and Discussion}

\subsection{Unit Root Tests}

The Augmented Dicky-Fuller unit root test was conducted on the variables and the results are shown in Table 1.

Table 1. Augmented dickey-fuller unit root test

\begin{tabular}{lcc}
\hline Variable & ADF (constant) & ADF (trend and constant) \\
\hline LnnomGDP & - & $-2.674(0)$ \\
$\Delta$ lnnomGDP & $9.021^{* *}(0)$ & - \\
InCPI & - & $-1.361(2)$ \\
$\Delta$ InCPI & $3.822^{* *}(1)$ & - \\
Inimports & - & $-1.452(2)$ \\
$\Delta$ lnimports & $4.613^{* *}(1)$ & - \\
Govtexp & - & $-1.401(1)$ \\
$\Delta$ Govtexp & $-7.643^{* *}(0)$ & - \\
InCedi-Dollar & - & $-1.906(4)$ \\
In $\Delta$ Cedi-Dollar & $-2.911^{*}(3)$ & - \\
InCedi-Pound & - & $-1.21(0)$ \\
In $\Delta$ Cedi-pound & $-8.902 * *(0)$ & - \\
InDomestic credit & - & $-1.212(0)$ \\
In $\Delta$ Domestic credit & $-8.731^{* *}(0)$ & \\
\hline
\end{tabular}

Source: Computed from data from Bank of Ghana, International Financial Statistics, Ghana Statistical Service, 2012.The numerical figures in parenthesis indicate the number lags required to remove autocorrelation.

** the unit root hypothesis rejected at $1 \%$ * the unit root hypothesis rejected at $5 \%$.

The Augmented Dicky-Fuller (ADF) test results show that all the variables are nonstationary in log levels at one percent significant level. That is to say, the unit root hypothesis is accepted in all cases. When the variables are 
first differenced, the unit root hypothesis is rejected in all cases.

\subsection{Cointegration Analysis}

Two sets of models are estimated-inclusion of Cedi-Dollar exchange rate in a model precludes the Cedi-Pound exchange rate and vice versa. Johansen cointegration approach, which is multivariate, is adopted in this study and the optimal lag length for the VAR is pre-determined using Hannan-Quinn (HQ) criterion. Table 2 shows the HQ values at various lag length in a VAR with constant and deterministic trend for the model containing Cedi-Dollar exchange rate.

Table 3. Test of optimal lag length for Cedi-Dollar model

\begin{tabular}{ccc}
\hline Lag & Hannan-Quinn $(\mathrm{HQ})$ & Akaike Information criterion \\
\hline 1 & -31.2453 & -31.8715 \\
2 & $-31.6012^{*}$ & -32.5271 \\
3 & -30.6724 & -32.0435 \\
4 & -29.8712 & -31.5631 \\
5 & -29.2768 & -31.4769 \\
6 & -28.4325 & -31.5790 \\
\hline
\end{tabular}

Source: Computed from data from Bank of Ghana, International Financial Statistics, Ghana Statistical Service, 2012.

The optimal lag length for the unrestricted VAR based on HQ criterion is two. This is confirmed by Akaike Information criterion (AIC). Table 3 shows the HQ values at various lag length in a VAR with constant and deterministic trend for the model containing Cedi-Pound exchange rate.

Table 4. Test of optimal lag length for Cedi-Pound model

\begin{tabular}{ccc}
\hline Lag & Hannan-Quinn $(\mathrm{HQ})$ & Akaike Information criterion \\
\hline 1 & -31.0145 & -31.6024 \\
2 & $-31.1672^{*}$ & $-32.1682^{*}$ \\
3 & -30.1561 & -31.4354 \\
4 & -29.4806 & -31.2492 \\
5 & -28.6543 & -30.7654 \\
6 & -27.6721 & -30.2314 \\
\hline
\end{tabular}

Source: Computed from data from Bank of Ghana, International Financial Statistics, Ghana Statistical Service, 2012.

The optimal lag length for the unrestricted VAR is two using Hannan-Quinn criterion for both models. This optimal lag length is also confirmed by the Akaike Information criterion. The VAR models are then reformulated as VECM and estimated using Full Information Maximum Likelihooh (FIML) Procedure. The cointegration results are presented in Table 5 for the model with Cedi-Dollar exchange rate.

Table 5. Johansencointegration test for Cedi-Dollar model

\begin{tabular}{ccccc}
\hline Eigenvalue & Trace statistic & $5 \%$ & $1 \%$ & Null hypothesis \\
\hline 0.29234 & 108.76435 & 94.11 & 103.15 & None ** \\
0.313345 & 73.08742 & 68.46 & 76.12 & At most 1 * \\
0.174238 & 38.37562 & 47.13 & 53.56 & At most 2 \\
0.152341 & 19.14503 & 29.86 & 35.75 & At most 3 \\
0.043588 & 4.163256 & 15.01 & 20.14 & At most 4 \\
0.000125 & 0.011420 & 3.82 & 6.71 & At most 5 \\
\hline
\end{tabular}

Source: Computed from data from Bank of Ghana, International Financial Statistics, Ghana Statistical Service, 2012.The test assumes linear deterministic trend the data.

** significant at $1 \%$. significant at $5 \%$. 
The trace statistic indicates two long run equilibrium relationships among the Cedi-Dollar exchange rate, consumer price index, nominal GDP, imports, government expenditure and domestic credit at both one and five percent significance levels. The first null hypothesis of zero cointegrating vector is rejected at both one and five percent significance levels. The second null hypothesis of at most one cointegrating vector is rejected at five percent level of significance but accepted at one percent level of significance. The third null hypothesis of at most two cointegrating vectors is not rejected at both one percent and five percent levels of significance and this ends the test. With respect of the VAR model including Cedi-Pound exchange rates, the result obtained from the estimation are displayed in Table 6.

Table 6. Johansen cointegration test for Cedi-Dollar model

\begin{tabular}{ccccc}
\hline Eigenvalue & Trace statistic & $5 \%$ & $1 \%$ & Null hypothesis \\
\hline 0.333563 & 110.7765 & 94.16 & 103.21 & None ** \\
0.313452 & 73.61153 & 68.73 & 76.01 & At most 1 \\
0.194886 & 39.54432 & 47.11 & 54.51 & At most 2 \\
0.213314 & 19.34425 & 29.74 & 35.54 & At most 3 \\
0.041272 & 3.912231 & 15.21 & 20.01 & At most 4 \\
0.000162 & 0.021443 & 3.74 & 6.56 & At most 5 \\
\hline
\end{tabular}

Source: Computed from data from Bank of Ghana, International Financial Statistics, Ghana Statistical Service, 2012.

$* *$ rejection at $1 \%$. ${ }^{*}$ rejection at $5 \%$.

The test assumes linear deterministic trend the data.

The first null hypothesis of no cointegrating vector is rejected at both one and five percent significance levels. The second null hypothesis of at most one cointegrating vector is rejected at five percent but accepted at one percent significance level. However, the null hypothesis of at most two cointegrating vectors is not rejected at both one and five percent levels of significance. It can, therefore, be concluded that there are at most two long run relationships among the Cedi-Pound exchange rate, consumer price index, government expenditure, imports, domestic credit and nominal GDP.

\subsection{Cointegration Regression}

Cointegration tests only indicate the fact that long run relationships exist among the variables without specifying which variables are actually cointegrating. Likelihood Ratio (LR) test was used to determine which variables to exclude from the long run relationships. Table 7 shows the results of the likelihood ratio test.

Table 7. Likelihood ratio test

\begin{tabular}{lcc}
\hline Variables (excluded) & Cedi-Dollar ModelLR statistic & Cedi-Pound ModelLR Statistic \\
\hline In(domcredit) & $4.441^{*}$ & $4.210^{*}$ \\
In(cpi) & $5.562^{*}$ & $5.032^{*}$ \\
In(imports) & $5.012^{*}$ & $4.234^{*}$ \\
In(nomgdp) & 2.257 & 1.762 \\
In(govexp) & $7.4533^{*}$ & $5.345^{*}$ \\
\hline
\end{tabular}

Source: Computed from data from Bank of Ghana, International Financial Statistics, Ghana Statistical Service, 2012.

* The null hypothesis is rejected at 5 percent significance level.

The 5 percent point of $X^{2}(1)$ is 3.841 showing that nominal GDP should be excluded from the long run relationships since the null hypothesis of insignificance is not rejected. The results from the estimation of the long run relationship excluding nominal GDP are shown in Table 8. 
Table 8. Long run equilibrium relationships

\begin{tabular}{lcc}
\hline Variables (excluded) & Cedi-Dollar ModelCoefficient & Cedi-Pound ModelCoefficient \\
\hline In(domcredit) & 0.74542 & 0.53422 \\
In(CPI) & 2.43654 & 3.21543 \\
In(import) & -1.34532 & -0.14553 \\
In(nomgdp) & 1.21433 & 0.42315 \\
In(govexp) & 7.12762 & 3.32667 \\
\hline
\end{tabular}

Source: Computed from data from Bank of Ghana, International Financial Statistics, Ghana Statistical Service, 2012.

It must be noted here that since all the variables are in logs, the coefficients of the long run static relationships must be interpreted as percentage changes (or elasticities) rather than unit changes. With respect to the Cedi-Dollar model, 100 percent increase in domestic credit, CPI and government expenditure increases the Cedi-Dollar rate by approximately 67 percent, 240 percent and 120 percent respectively in the long run, A 100 percent increase in import, however, causes the Cedi-Dollar rate to fall by 135 percent. The CPI had the largest effect on the exchange rate while domestic credit had the least effect. Regarding the Cedi-Pound model, 100 percent increase in domestic credit, CPI and government expenditure increase the Cedi-Pound rate by approximately 54 percent, 322 percent and 42 percent in the long run. However, 100 percent increase in import causes the Cedi-Pound rate to fall by 15 percent in the long run. Again the CPI has the greatest impact on the rate while import has the least long run effect on the Cedi-Pound rates.

\subsection{Error Correction Model}

The outputs form the VECM estimation are so huge and for that matter, they are presented in Appendixes A and B. From the Cedi-Dollar model, the error correction term is correctly signed and significant at five percent level indicating that economic forces are in place to ensure the return of the Cedi-Dollar rate to its long run path. The coefficient of the error correction term indicates that about nine percent (9\%) disequilibrium is eliminated each quarter by changes in the Cedi-Dollar rate to ensure that the rate returns to its long run path. The past history of the Cedi-Dollar rate and government expenditure are significant at one and five percent respectively in causing the exchange rate to deviate from its long run path. The CPI, domestic credit, imports and nominal GDP are not significant at the conventional levels. The past history of Cedi-Dollar rate, government expenditure, the CPI and domestic credit have the expected signs. With respect to the Cedi-Pound model, the coefficient of the error correction term is significant at one percent signifying that economic forces in place ensure the return of the Cedi-Dollar rate to its equilibrium path following short run deviation. The coefficient of the error correction term indicates that about twenty four percent disequilibrium in the Cedi-Pound rates is corrected each quarter by changes in the Cedi-Pound rate. While the past history of the Cedi-Pound rates is significant at five percent, government expenditure and the CPI are significant at one percent and also have the expected signs. Domestic credit, imports and nominal GDP are not significant at the conventional levels. The domestic credit, however, has the expected sign. As noted earlier, the error correction terms used as variables in the VECM are actually equilibrium residuals obtained from the cointegrating regressions. In the Cedi-Dollar model for instance, the first error correction term, Eq.1 (-1), is obtained from the following equation:

$$
\begin{aligned}
& \text { Eq1(-1) = LNCEDD }-7.641-0.64(\text { Indomcredit })-2.46(\text { Incpi }) \\
& +1.31(\text { In } \operatorname{Im} \text { port })+0.19(\text { Innomgdp })-1.32(\text { Ingovexp })
\end{aligned}
$$

Similarly, the second error correction term, $E q .2(-1)$, is generated from the equation:

$$
\begin{aligned}
& E q 2(-1)=L N G O V E X P+1.51-0.011(\text { Indomcredit })-0.44(\text { Incpi }) \\
& -0.158(\text { In } \operatorname{Im} \text { port })-0.61(\text { Innom } g d p)-0.03(\text { Incedd })
\end{aligned}
$$

In the Cedi-Pound model, the same logic is used to obtain the two error correction terms, i.e. LNCEDD is replaced by LNCEDP. Eviews software generates these error correction terms by itself once the long run restriction is imposed and uses them as variables in the VECM.

\subsection{Granger Causality Test}

A model containing the Cedi-Dollar exchange rates as the endogenous variable is estimated and the granger causality test results of the model are displayed in the Table 9 . 
Table 9. Granger causality test for cedi-dollar rate

\begin{tabular}{ll}
\hline Variables & F-statistic \\
\hline InCedi-Dollar (-1) & $19.812^{* *(1,86)}$ \\
InDomestic Credit (-1) & $1.8748(1,86)$ \\
Ingovexp (-1) & $5.236 *(1,86)$ \\
Inimports (-1) & $0.0141(1,86)$ \\
InConsumer Price Index (-1) & $0.83542(1,86)$ \\
Innominal GDP (-1) & $1.714(1,86)$ \\
Bresusch-Godfrey autocorrelation test & $X_{d f=5}^{2}=6.117$ \\
\hline
\end{tabular}

Source: Computed from data from Bank of Ghana, International Financial Statistics, Ghana Statistical Service, 2012.The granger causality test follows the approach described in Gujarati (2004).** significant at $1 \%$ * significant at $5 \%$.

It can be observed from Table 9 that imports, domestic credit, CPI and nominal GDP individually do not granger cause the Cedi-Dollar rate. The null hypothesis that imports, domestic credit, CPI and nominal GDP contain useful information in forecasting the Cedi-Dollar rate is rejected at five percent level. However, the lagged Cedi-Dollar rate and government expenditure contain useful information in forecasting the Cedi-Dollar rate. In other words, Cedi-Dollar rate and government expenditure granger the Cedi-Dollar rate. While the Cedi-Dollar rate is significant at one percent level, government expenditure is significant at five percent level. The test results with respect to the CPI confirm earlier studies (Corbea \& Ouliaris, 1988; Frenkel, 1981).

With respect to the Cedi-Pound model, the results of the granger causality test are shown in Table 10.

Table 10. Granger causality test for cedi-pound rate

\begin{tabular}{ll}
\hline Variables & F-statistic \\
\hline InCedi-Dollar (-1) & $13.16^{* *}(1,86)$ \\
InDomestic Credit (-1) & $0.2567(1,86)$ \\
Ingovexp (-1) & $4.4621^{*}(1,86)$ \\
Inimports (-1) & $0.82764(1,86)$ \\
InConsumer Price Index (-1) & $2.0774(1,86)$ \\
Innominal GDP (-1) & $0.2356(1,86)$ \\
Bresusch-Godfrey autocorrelation test & \\
\hline
\end{tabular}

Source: Computed from data from Bank of Ghana, International Financial Statistics, Ghana Statistical Service, 2012.** significant at 1\%.* significant at $5 \%$.

It can be seen from Table 10 that the domestic credit, CPI, imports and nominal GDP contain no useful information in predicting the Cedi-Pound rate. The implication is that these variables do not granger cause the Cedi-Pound rate.

The lagged Cedi-Pound rate and government expenditure granger cause the Cedi-Pound rate. While the Cedi-Pound rate is significant at one percent level, government expenditure is significant at five percent level.

\subsection{Forecasting with VAR}

One of the good properties of an econometric model is its ability to forecast the variables that are being modeled. In this study, we estimate the VAR using data from 1985:1 to 2006:4 and forecast the exchange rate eight steps ahead. Results from this estimation and testing are shown in Table 11.

Table 11. Dynamic forecast for cedi-dollar exchange rate

\begin{tabular}{cccccc}
\hline Horizon & Forecast & SE & Actual & Error & t-ratio \\
\hline $2007-1$ & 9.12564 & 0.07812 & 9.12763 & -0.007823 & -0.096 \\
$2007-2$ & 9.15612 & 0.1324 & 9.14332 & -0.022554 & -0.186 \\
$2007-3$ & 9.18465 & 0.2453 & 9.23745 & -0.0378603 & -0.345 \\
$2007-4$ & 9.23253 & 0.2354 & 9.23546 & -0.0546378 & -0.346 \\
$2007-1$ & 9.35476 & 0.2200 & 9.28465 & -0.1457632 & -0.330 \\
$2007-2$ & 9.31402 & 0.2432 & 9.23457 & -0.0756479 & -0.325 \\
$2007-3$ & 9.45637 & 0.2635 & 9.34112 & -0.0235698 & -0.085 \\
$2007-4$ & 9.40745 & 0.3457 & 9.40187 & -0.0057120 & -0.022 \\
\hline
\end{tabular}

Source: Computed from data from Bank of Ghana, International Financial Statistics, Ghana Statistical Service, 2012.MAPE = 0.407; Standard Error $(\mathrm{SE})$ is based on error variance only. Mean $($ Error $)=-0.0378$. RMSE $=0.0452$ (Error) $=0.025$. 
From Table 11, it can be observed that all the t-ratios are not significant implying that the forecast values, on the average, are not significantly different from the actual data points. For the model involving the Cedi-Pound exchange rate, reduced rank regression reflecting the number of cointegrating vectors is run. The model is then used to forecast the Cedi-Pound rate eight period ahead and these forecast values compared with the reserved data points. The outcome of the forecast and the test for significant difference between actual and forecast values are presented in Table 12.

Table 12. Dynamic forecast for cedi-dollar exchange rate

\begin{tabular}{cccccc}
\hline Horizon & Forecast & SE & Actual & Error & t-ratio \\
\hline $2007-1$ & 9.79208 & 0.0939 & 9.78670 & -0.0074589 & -0.079 \\
$2007-2$ & 9.81548 & 0.1300 & 9.83346 & 0.0161186 & 0.130 \\
$2007-3$ & 9.79280 & 0.1460 & 9.94375 & 0.0198459 & 0.134 \\
$2007-4$ & 9.87543 & 0.1832 & 9.94577 & 0.0196753 & 0.103 \\
$2007-1$ & 9.91457 & 0.2043 & 9.94632 & -0.0190233 & -0.149 \\
$2007-2$ & 9.94701 & 0.2242 & 9.91745 & -0.0424463 & -0.232 \\
$2007-3$ & 9.97303 & 0.2307 & 9.87373 & -0.0723672 & -0.284 \\
$2007-4$ & 10.0372 & 0.2514 & 9.70477 & -0.277389 & -0.912 \\
\hline
\end{tabular}

Source: Computed from data from Bank of Ghana, International Financial Statistics, Ghana Statistical Service, 2012.Mean $($ Error $)=-0.0397$. RMSE $=0.0884$. SD $($ Error $)=0.0789, \mathrm{MAPE}=0.5407$.

It can be observed from Table 12 that all the t-ratios are not significant implying that the forecasts are not statistically different from the actual realizations.

\subsection{Variance Decomposition}

In this section, we report the percentage contribution of shocks emanating from the Cedi-Dollar rate, CPI, government expenditure, domestic credit, imports and nominal GDP in forecasting the Cedi-Dollar exchange rate over ten quarters following one standard deviation shock to the Cedi-Dollar rate. The results are shown in Table 13 .

Table 13. Variance decomposition of cedi-dollar rate

\begin{tabular}{lccccccc}
\hline \multicolumn{2}{l}{ Period S.E } & Cedi-D & CPI & Domcr & Gov & Import & GDP \\
\hline 1 & 0.06 & 99.7 & 0.00 & 0.00 & 0.00 & 0.00 & 0.00 \\
2 & 0.10 & 95.24 & 0.62 & 0.53 & 2.72 & 0.22 & 0.53 \\
3 & 0.15 & 92.18 & 1.23 & 0.45 & 4.24 & 0.52 & 1.21 \\
4 & 0.16 & 89.66 & 1.74 & 0.43 & 5.47 & 0.87 & 1.94 \\
5 & 0.20 & 87.12 & 2.16 & 0.33 & 6.24 & 1.33 & 2.53 \\
6 & 0.21 & 85.34 & 2.50 & 0.27 & 6.87 & 1.72 & 3.10 \\
7 & 0.23 & 83.88 & 2.76 & 0.21 & 7.41 & 2.05 & 3.50 \\
8 & 0.27 & 82.60 & 3.01 & 0.23 & 7.72 & 2.33 & 4.00 \\
9 & 0.28 & 81.34 & 2.20 & 0.27 & 8.11 & 2.54 & 4.33 \\
10 & 0.30 & 80.59 & 3.31 & 0.31 & 8.34 & 2.76 & 4.64 \\
\hline
\end{tabular}

Source: Computed from data from the Bank of Ghana, International Financial Statistics, Ghana Statistical Service, 2012.

It can be observed in Table 13 that the shock to the Cedi-Dollar exchange rate in the first quarter comes completely from the shock in the foreign exchange market. In the second quarter, about $95 \%$ variation in the Cedi-Dollar rate is contributed by shocks from the foreign exchange market, followed by about $3 \%$ shock from government expenditure. The rest of the variables contribute less than one percent respectively to the variation in the Cedi-Dollar rate. In the sixth quarter, shocks from the Cedi-Dollar rate accounts for about $85 \%$ of total variation in the Cedi-Dollar rate, followed by $7 \%$ from the government expenditure and the shocks coming from CPI, domestic credit, imports and nominal GDP respectively account for less than 5\% shock to the Cedi-Dollar rate. In the last quarter, about $80 \%$ of the shocks in the Cedi-Dollar rate is explained by shocks from the past Cedi-Dollar exchange rate. Approximately $8 \%$ of the shock to the exchange rate is coming from shocks to government expenditure. The CPI, domestic credit, imports and nominal GDP respectively account for less than 5\% of the shock to the Cedi-Dollar rate. In all, most of the shocks to the Cedi-Dollar rate over the period come from shocks in the past history of the exchange rate, followed by government expenditure, nominal GDP, CPI, imports and domestic credit in that order. 
With regard to Cedi-Pound exchange rate, the effect of a shock to the Cedi-Pound rate on the future value of the Cedi price of British Pound over the forecast period as shown in Table 14. It can be observed from Table 14 that a shock to the Cedi-Pound market in the first quarter account for all the shocks to the Cedi-Pound rate in that period. In the second quarter, the Cedi-Pound rate is explained by about $93 \%$ of own shocks, followed by $3 \%$ shocks from CPI and nominal GDP, imports, domestic credit and government expenditure respectively contribute less than $2 \%$ variation in the exchange rate shock.

Table 14. Variance decomposition of cedi-pound rate

\begin{tabular}{llcccccc}
\hline \multicolumn{2}{l}{ Period S.E } & Cedi-P & CPI & Domcr & Govexp & Imports & GDP \\
\hline Q1 & 0.07 & 100.0 & 0.00 & 0.00 & 0.00 & 0.00 & 0.00 \\
Q2 & 0.12 & 93.16 & 2.73 & 1.51 & 1.42 & 0.65 & 0.32 \\
Q3 & 0.13 & 85.92 & 4.83 & 3.86 & 2.13 & 2.64 & 0.45 \\
Q4 & 0.17 & 76.43 & 6.12 & 5.47 & 2.45 & 5.51 & 0.68 \\
Q5 & 0.17 & 74.21 & 7.10 & 6.32 & 2.43 & 8.91 & 0.94 \\
Q6 & 0.23 & 69.63 & 7.78 & 6.10 & 2.67 & 12.41 & 1.43 \\
Q7 & 0.21 & 66.06 & 8.35 & 5.87 & 2.76 & 14.65 & 2.02 \\
Q8 & 0.22 & 62.81 & 8.93 & 5.51 & 2.96 & 17.04 & 2.70 \\
Q9 & 0.24 & 60.16 & 9.31 & 5.03 & 3.12 & 18.93 & 3.30 \\
Q10 & 0.25 & 57.83 & 9.74 & 4.61 & 3.22 & 20.52 & 3.82 \\
\hline
\end{tabular}

Source: Computed from data from Bank of Ghana, International Financial Statistics, Ghana Statistical Service, 2012.

In the fifth quarter, about $74 \%, 9 \%, 7 \%$ and $6 \%$ variation in the Cedi-Pound rate is explained by own shocks, imports shocks, CPI shocks and domestic credit shocks respectively. Shocks coming from government expenditure and nominal GDP respectively account for less than 3\% shocks to the Cedi-Pound rate. In the eighth quarter, about $63 \%, 17 \%, 9 \%$ and $6 \%$ variation in the Cedi-Pound rate is explained by own shocks, imports shocks, CPI shocks and domestic credit shocks respectively. Shocks coming from government expenditure and nominal GDP respectively account for less than $3 \%$ variation in the Cedi-Pound rate. In the last quarter, about $58 \%, 21 \%, 10 \%$ and $5 \%$ variation in the Cedi-Pound rate is explained by own shocks, imports shocks, CPI shocks and domestic credit shocks respectively. Shocks coming from government expenditure and nominal GDP respectively account for less than $4 \%$ variation of in the Cedi-Pound rate. In all, Cedi-Pound rate is explained mainly by own shocks, imports shocks and CPI shocks.

\section{Conclusion}

The principal objective of this study is to investigate the possible determinants of exchange rates in Ghana using the techniques of cointegration and error correction modeling. The study revealed that two major factors were responsible for the upward surge in the exchange rates, namely the government expenditure and the past history of the exchange rates. Secondly, it was discovered that long run relationships tie the exchange rates to the CPI, nominal GDP, domestic credit, government expenditure and imports. Thirdly, expansionary fiscal and monetary policies were found to cause the Cedi price of Dollar and Pound to rise sharply and persistently. Finally, it was discovered that the Cedi-Pound rate converged faster to equilibrium than the Cedi-Dollar rate. Considering the impact of government expenditure on future movements in the exchange rates, it is recommended that fiscal expansion should be moderate. This is to ensure that exchange rate volatility is minimal. The substantial foreign exchange reserves should be built by the central bank considering the length of time it takes the exchange rates to return to their equilibrium values. This is to ensure that in times of exogenous shocks, whose impact on the exchange rate may take a long time to diminish, the central bank could intervene to minimize the impact of the shocks. It is recommended that expansionary monetary policy should be gradual considering the drastic effect of credit expansion on exchange rates as demonstrated by the impulse response functions. In this direction, banks could be encouraged to support the export sector as against the import businesses that tend to increase demand for foreign exchange.Finally, policymakers should pay attention to the developments in the CPI as increase in the CPI tend to have depreciating effect on the Cedi as revealed by the impulse response functions.

\section{References}

Abuaf, N., \& Jorion, P. (1990). Purchasing power parity in the long run. The Journal of Finance, 157-174. http://dx.doi.org/10.1111/j.1540-6261.1990.tb05085.x

Bergstand, J. H. (1991). Structural determinants of real exchange rates and national price levels: Some empirical evidence. The American Economic Review, 81, 325-334. Retrieved from http://www.nber.org/papers/w7228.reftxt 
Bhasin, K. V. (2004). Reaction functions of the bank of Ghana: dynamic interlinks among the exchange rate, price level and terms of trade in a managed floating exchange rate system: The case of Ghana. African Economic Research Consortium Research Paper, 141.

Calderon, C., \& Duncan, R. (2003). Purchasing power parity in an emerging market economy: A long-span study for Chile. Estudios de Economia, 30, 103-132.

Cheung, Y., \& Lai, K. S. (2001). Long memory and nonlinear mean reversion in Japanese Yen-based real exchange rates. Journal of International Money and Finance, 2, 115-132.http://dx.doi.org/10.1016/S0261-5606(00)00037-1

Corbea, D., \& Ouliaris, S. (1998). Cointegration and tests of purchasing power parity. The Review of Economics and Statistics, 70, 508-511.http://dx.doi.org/10.2307/1926790

Dibooglu, S., \& Enders, W. (2001). Long run purchasing power parity with asymmetric adjustment. Southern Economic Journal, 68, 433-455.http://dx.doi.org/10.2307/1061603

Diebold, F. X., Husted, S., \& Rush, M. (1991). Real exchange rates under the Gold Standard. The Journal of Political Economy, 99, 1251-1271.http://dx.doi.org/10.1086/261799

Dordunoo, C. K. (1994). The foreign exchange market and the Dutch auction system in Ghana. African Economic Research Consortium Research Paper 24.

Dornbusch, R. (1976). Expectations and exchange rate dynamics. Journal of Political Economy, 84, 1161-1176.http://dx.doi.org/10.1086/260506

Dumas, B. (1992). Dynamic equilibrium and the real exchange rate in a spatially separated world. The Review of Financial Studies, 5, 153-180. http://dx.doi.org/10.1093/rfs/5.2.153

Edison, H. J., \& Pauls, B. D. (1993). A re-assessment of the relationship between real exchange rates and real interest rates, 1974-1990. Journal of Monetary Economics, 31, 165-87. http://dx.doi.org/10.1016/0304-3932(93)90043-F

Eichenbaum, M., \& Evans, C. L. (1995). Some empirical evidence on the effects of shocks to monetary policy on exchange rates. The Quarterly Journal of Economic, 110, 975-1009. http://dx.doi.org/10.2307/2946646

Engle, R. F., \& Granger, C. W. J. (1987). Co-integration and error correction: Representation, estimation, and testing. Econometrica, 55, 251-276.http://dx.doi.org/10.2307/1913236

Frenkel, J. A. (1976). A monetary approach to the exchange rate: doctrinal aspects and empirical evidence. Scandinavian Journal of Economics, 78(2), 200-224. http://dx.doi.org/10.2307/3439924

Frenkel, J. A. (1980). Exchange rates, prices and money: lessons from the 1920s. The American Economic Review, 70, 242-255. Retrieved from www.nber.org/chapters/c11681.pdf

Government of Ghana. (1995). Ghana vision 2020: the first step: 1996-2000. Accra: National Development Planning Commission, Accra.

Granger, C. W. J. (1983). Cointegrated variables and error correction models. Discussion Paper, 83-13a, University of California, San Diego.

Granger, C. W. J., \& Newbold, P. (1973). Spurious regressions in econometrics. Journal of Econometrics, 2, 111-120. http://dx.doi.org/10.1016/0304-4076(74)90034-7

Granger, C. W. J., \& Terasvirta, T. (1993). Modelling non-linear economic relationships. Oxford: Oxford Univ. Press.

Greene, W. H. (2002). Econometric analysis. New Jersey: Pearson Education Inc.

Harrigan, J., \& Oduro, A. D. (2000). Exchange rate policy and the balance of payments 1972-1996 (pp. 153-184). Economic Reforms in Ghana: the miracles and the mirages.

Hendry, D. F., \& Juselius, K. (2000). Explaining cointegration analysis: Part II. Department of Economics, Oxford University, UK and Department of Economics, University of Copenhagen, Denmark.

Jebuni, C. D., Sowa, N. K., \& Tutu, K. A. (1991). Exchange rate policy and macroeconomic performance in Ghana. African Economic Research Consortium Research Paper, 6.

Johansen, S. (1988). Statistical analysis of cointegration vectors. Journal of Economic Dynamics and Control, 2, 231-254. http://dx.doi.org/10.1016/0165-1889(88)90041-3 
Kouretas, G. P. (1997). Identifying linear restrictions on the monetary exchange rate model and the uncovered interest parity: Cointegration evidence from the Canadian-U.S. Dollar. The Canadian Journal of Economics, 30, 875-890. http://dx.doi.org/10.2307/136275

Kwakye, J. K., \& Sowa, N. K. (1993). Inflationary trends and control in Ghana. African Economic Research Consortium research paper 22 .

MacDonald, M. (1993). Long run purchasing power parity: is it for real? The Review of Economics and Statistics, 75, 690-695.http://dx.doi.org/10.2307/2110023

Officer, L. O. (1981). The floating dollar in the greenback period: A test of theories of exchange-rate $\begin{array}{lllll}\text { determination. The Journal of History, } & \text { 4l, }\end{array}$ 629-650.http://dx.doi.org/10.1017/S0022050700044363

Oracn, M. K. (2007). A modeling of Ghana's inflation experience. African Economic Research Consortium, research paper 169.

Osei, K. A. (1996). Foreign exchange bureaus in the economy of Ghana. African Economic Research Consortium research Paper, 45.

Perron, P. (1990). Testing for a unit root in a time series with a changing mean. Journal of Business of Economic Statistics, 8, 153-162.

Phillips, P. C. B., \& Perron, P. (1987). Testing for a unit root in time series regression. Cowles Foundation for Research in Economics, Yale University.

Sarno, L., \& Taylor, M. (1998). Purchasing power parity and the real exchange rate. IMF Staff Paper, 49, 65-104.

Sercu, P., Uppal, R., \& Hulle, C. V. (1995). The exchange rate in the presence of transaction costs: implications for tests of purchasing power parity. The Journal of Finance, 50, 1309-1319. http://dx.doi.org/10.1111/j.1540-6261.1995.tb04060.x

\section{Copyrights}

Copyright for this article is retained by the author(s), with first publication rights granted to the journal.

This is an open-access article distributed under the terms and conditions of the Creative Commons Attribution license (http://creativecommons.org/licenses/by/3.0/). 